\title{
Phanerozoic Evolution of the Subcontinental Lithospheric Mantle, Eastern North China Block: Mantle Xenolith Evidence
}

\author{
Zheng, Jianping. ${ }^{1,2}$
}

1. School of Earth Sciences, China University of Geosciences, Wuhan, 430074, China

2. GEMOC, School of Earth Sciences, Macquarie University, NSW 2109, Australia

Palaeozoic diamond- and xenolith-bearing kimberlites Cenozoic xenolith-bearing basalts, erupted in the North China Block (NCB), provide excellent mantle probes for research on intraplate processes and the Phanerozoic evolution of Subcontinental Lithospheric Mantle (SCLM). In this study, the mineral inclusions in diamonds and xenoliths from Mengyin (Shandong province) and Fuxian (Liaoning province) kimberlites are chosen to constrain the nature of Palaeozoic Subcontinental Lithospheric Mantle (P-SCLM), while xenoliths from the Shanwang and Qixia basalts (in Shandong province) are chosen to constrain the natures of Cenozoic Subcontinental Lithospheric Mantle (C-SCLM). Shanwang lies astride the Tancheng-Lujiang (Tanlu) fault zone, a major lithospheric fault in eastern China, and Qixia lies east of the fault zone.

\section{Petrography of xenoliths}

The inclusions in diamonds reflect the assemblages of low-Ca harzburgite (mainly) and cpx-poor lherzolite bearing garnet. Mantle xenoliths from the P-SCLM include harzburgite, garnet and/or chromite lherzolite (mainly), dunite, wehrlite, mantle pegmatites, pyroxenite, mafic granulite, gabbro, phlogopitite and eclogite. The Fuxian xenoliths contain a higher proportion of lherzolite, pyroxenite and phlogipitite than do the Mengyin ones. The peridotitic xenoliths mainly show sheared microstructure, with a small proportion of granular and metasomatic textures. The complexity of the xenoliths shows evidence of multiple events such as deformation, metasomatism and recrystalization in the mantle. In contrast, most of the basalt-borne xenoliths are spinel lherzolite exhibiting typical textures of mantle xenoliths (eg. porphyroclastic), without metasomatic textures. There contrasts indicates that the C-SCLM in the region has a relatively simple history of evolution, thus precluding the possibility that the C-SCLM is the residual of the P-SCLM. The basalt-borne peridotite xenoliths vary petrographically with their locations relative to the Tanlu fault. For instance, the Shanwang xenolith suite contains a larger proportion of samples with finegrained or sheared microstructure, higher abunances of modal clinopyroxene than the Qixia ones.

\section{Mineral Chemistry}

$\mathrm{Mg} \#$ values of olivine show a decreasing trend from diamond inclusions (ave. 0.92), though lherzolites of the P-SCLM (0.915) to lherzolites of the C-SCLM $(\leq 0.91)$, indicating that the mantle beneath the NCB became fertile though time. The peridotites from the C-SCLM are typical of "Oceanic", rather than of Archean or Proterozoic lithospheric mantle. $\mathrm{Zr} / \mathrm{Y}$ vs Y/Ga relationships (Griffin et al., 1997) demonstrate that the garnets from diamond inclusions plot in the Arcton field (Zhang et al., 1997). In contrast, only some of the garnets in the kimberlite-borne xenoliths or as xenocrysts plot in the Arcton field. The majority plot either in the Proton field or below the Arcton-Proton-Tecton trend. It remains a question about the mechanism for the change of garnet compositions in the kimberlite-borne xenoliths. The Cenozoic garnets from Nushan plot in Tecton field (Xu et al., 1997). Mantle clinopyroxenes from Shanwang are LREE-enriched, whereas many samples from Qixia are depleted in LREE. The Tanlu fault may have served as a conduit for the metasomatic fluid/melt.

\section{Geochemistry}

The P-SCLM is chemically heterogeneous. Although they all show LREE-enrichment, the Fuxian garnet lherzolites contain both higher abundances of basaltic components (eg. $\mathrm{CaO}$ and $\mathrm{Al}_{2} \mathrm{O}_{3}$ ) and incompatible elements (eg. Nb, Ta, Zr, Hf, Th, U, REE, Rb, and $\mathrm{Sr}$ ) than the Mengyin xenoliths. Meanwhile, the peridotites with shear texture are more fertile than the granular ones. The C-SCLM differs from the P-SCLM in two ways. First, they are less depleted than the P-SCLM ones in terms of major elements. Second, the C-SCLM samples normally contain lower abundances of incompatible trace elements and lower LREE/HRRE ratios (some chondrite-like) than their P- 
SCLM counterparts. As demonstrated by petrography and mineral chemistry, the bulk chemical data (both major and trace elements) also indicate that the Shanwang spinel lherzolites are fertile and enriched in incompatible elements relative to the Qixia samples. All but one kimberlite-borne xenoliths in both provinces have EM2-type $\mathrm{Sr}-\mathrm{Nd}$ isotope ratios. However, the Fuxian samples have higher ${ }^{87} \mathrm{Sr} /{ }^{86} \mathrm{Sr}$ but lower ${ }^{143} \mathrm{Nd} /{ }^{144} \mathrm{Nd}$ than the Mengyin samples. They are also high in ${ }^{206} \mathrm{~Pb} / 204 \mathrm{~Pb}\left(>19.5\right.$ vs < 18.7) and $\partial^{18} \mathrm{O} \%$ (5.2-7.3 vs $\left.4.2-4.5\right)$. Positive $\Delta 7 / 4 \mathrm{~Pb}$ and $\Delta 8 / 4 \mathrm{~Pb}$ values of all the xenolihts may reflect their Gondwana inheritance.

\section{Thermal State}

Thermal gradient drawn from garnet (Griffin et al., 1989) and pyroxene (Mercier, 1976) thermobarometry of xenoliths or xenocrysts in Mengyin and Fuxian kimberlites are higher than the $38 \mathrm{~mW} / \mathrm{m}^{2}$ thermal gradient calculated from the pyroxene inclusions in diamonds. The equilibrium pressure of xenoliths or xenocrysts from kimberlites is up to $65 \mathrm{~kb}$ with mainly $20-40 \mathrm{~kb}$. Metasomatism is obviously indicated by the presence of yimengite and lindsleyite at this level. This observation suggests that the low-Ca harzburgite (mainly) or cpx-poor lherzolite environment for diamond stability have been changed gradiently due to interaction between fluids/melts and the peridotites before eruption of the kimberlities. The equilibrum temperatures of spinel lherzolites are $850-1020^{\circ} \mathrm{C}$ at $15 \mathrm{~kb}$, reflecting a geotherm of the C-SCLM higher than the oceanic one. The calculated temperatures from Shanwang are $25-50{ }^{\circ} \mathrm{C}$ higher than from Qixia, showing that the Tanlu fault may have acted not only as the path for fluids/melts, but also for heat flux.

\section{Displacement of the Tanlu Fault}

$\mathrm{Xu}$ et al. (1987) suggested that the Tanlu fault is a sinistral fault with a offset of $750 \mathrm{~km}$, based on several lines of geological observations, including the distance between the Mengyin and Fuxian kimberlites on the opposite sides of the fault. Based on their studies of garnet separates from kimberlites, Griffin et al. (1997) argued that the two P-SCLM sections are petrologically different and thus the distance of the two kimberlites cannot be used as indicators of the displacement of the Tanlu fault. Our petrographic and geochemcal data for the mantle xenoliths from Mengyin and Fuxian, particularly the significant differences in their $\mathrm{Sr}-\mathrm{Nd}-\mathrm{Pb}-\mathrm{O}$ isotopic systematics, provide further evidence that the Mengyin and Fuxian kimberlites may have intruded into two different Archaean terranes rather than a uniform SCLM during Paleozoic time.

\section{Phanerozoic Evolution of the SCLM beneath the North China Block}

The nature of the SCLM evolution can be constrained in three time slices by the data discussed above: 1) the lithospheric mantle before the early-Palaeozoic emplacement of the kimberlites as reflected by the inclusions in diamonds; 2) the P-SCLM reflected by the xenoliths from kimberlites; and 3 ) the C-SCLM reflected by the xenoliths from basalts.

Based on the kinetics of nitrogen aggregation in diamond (Evans and Qi, 1982), estimated formation ages for the Fuxian diamonds are 1060-1200 Ma (8 grains, 1-2 mm in size) and $2200 \mathrm{Ma}$ $(>2 \mathrm{~mm})$. If the estimated values are reliable, it implies that the formation of diamonds was multiple stages. The multiple stages may have been connected with the multiple events of the mantle evolution. During this period, the cratonic mantle was refractory and in a low thermal gradient. This refractory mantle have been gradiently changed till the eruption of kimberlites. It was yet a think cold "root" or "keel" during this period. The P-SCLM was still refractory in major elements but enriched in trace element. A large variety of mafic xenoliths, including mafic granulite and gabbro, has been found in the same kimberlitic pipes, implying that several episodes of mafic magma underplating took place at crust-mantle boundary level. On the other hand, the abundant ultramafic xenoliths such as pyroxenites and phlogopites with complex textures may suggest that mantle events such as metasomatism, deformation and recrystallization took place in the P-SCLM during the period between the diamond formation and the kimberlite emplacement. We speculate that these events may have resulted in the formation of weak (or fracture) zones in the SCLM. Mantle pegmatites found as xenoliths in the kimberlites, possibly associated with melt/fluid activity, shear zone, and metasomatism in the mantle are rich in fluids, LREE and large ion lithophile elements (including heat-producing elements). The relationship between texture and chemistry of the peridotite xenoliths indicates that the deformed textures were genetically related to mantle shear zones which served as conduits for incompatible element enriched melts/fluids. 
The C-SCLM is fertile in major elements and depleted in trace elements relative to the P-SCLM. It is impossible that this relatively simple and homogeneous C-SCLM could have been derived from the the complex and heterogeneous P-SCLM simply by machenical attenuation and chemical modification. Replacement of the P-SCLM by materials from an upwelling asthenosphere must have occurred. Geophysical data (Yuan, 1996) demonstrate that the present lithosphere is thin (60$110 \mathrm{~km})$ and hot $\left(60-80 \mathrm{~mW} / \mathrm{m}^{2}\right)$, with many irregular, mushroom-like low-velocity bodies at the depths of 60-130 km. These hot bodies may reflect mantle weak zones and upwelling of the lower velocity materials is most obvious along the Tanlu fault. The collision between the South China Block and the NCB during the early Mesozoic (Yin and Nie, 1993) could have facilitated the development of these reticulated mantle weak zones, particularly along the Tanlu fault. Accompanied by the subduction of Pacific and/or Indian plates, upper mantle conviction became more vigorous beneath the NCB. The attenuation and replacement of the P-SCLM by upwelling asthenosphere materials through thermal erosion and possibly delamination resulted in the irregular-shaped hot bodies, mainly along weak zones, detected from geophysical data.

Acknowledgments: The abstract is a part of Ph. D thesis (supervisor: Prof. Lu Fengxiang). The author thank professors Lu Fengxiang, Suzanne Y. O'Reilly and William L. Griffin and Dr Ming Zhang for their kind help and many useful discussions.

\section{References}

Evans, T., and Qi, Z., 1982, The kinetics of the aggregation of nitrogen atoms in diamond: Proc. Roy. Soc., A381, p.159-178

Griffin, W. L., Cousens, D.R. and Ryan, C. G., 1989, Ni in chrome pyrope garnets: a new thermometer: Contributions to Mineralogy and Petrology, 103, p. 199-203

Griffin, W. L., Zhang, A. D., O'Reilly, S.Y., and Ryan, C.G., 1997, Phanerozoic evolution of the lithosphere beneath the Sino-Krean Craton: Amer. Geophysical Union Geodynamics series, Mantle Dynamics and Plate Interactions in East Asia, in press

Mercier, 1976, Single-pyroxene geothermometry and geobarometry: American Mineralogy, 61, p. 601-615

Xu, J. W., Zhu, G., Tong, W. X and Cui, K. R., 1987, Formation and evolution of the TanchengLujiang wrench fault system - a major shear system to the northwest of the Pacific Ocean: Tectonophysics, 134, p.273-310

Xu, X., O'Reilly, S. Y., Griffin, W. L., Zhou, X. \& Huang, X., 1997, The Nature of the Cenozoic lithosphere at Nushan, eastern China: Amer. Geophysical Union Geodynamics series, Mantle Dynamics and Plate Interactions in East Asia, in press

Yin, A. and Nie, S. Y., 1993, An indentation model for the North and South China collision and the development of the Tan-Lu and Honam fault systems, Eastern Asia: Tectonic, 12(4), p. 801 813

Yuan, X. C., 1996, Velocity structure of the Qinling lithosphere and mushroom cloud model: Science in China (Series D), 39(3), p. 235-244 